\title{
Apparatus for dry deposition of aerosols on snow
}

\author{
Nicholas D. Beres ${ }^{1,2}$ and Hans Moosmüller ${ }^{1}$ \\ ${ }^{1}$ Laboratory for Aerosol Science, Spectroscopy, and Optics, Desert Research Institute, Reno, NV 89512, USA \\ ${ }^{2}$ Department of Physics, University of Nevada-Reno, Reno, NV 89512, USA
}

Correspondence: Nicholas D. Beres (nic.beres@dri.edu)

Received: 15 June 2018 - Discussion started: 11 July 2018

Revised: 4 December 2018 - Accepted: 6 December 2018 - Published: 21 December 2018

\begin{abstract}
Deposition of light-absorbing aerosol on snow can drastically change the albedo of the snow surface and the energy balance of the snowpack. To study these important effects experimentally and to compare them with theory, it is desirable to have an apparatus for such deposition experiments. Here, we describe a simple apparatus to generate and evenly deposit light-absorbing aerosols onto a flat snow surface. Aerosols are produced (combustion aerosols) or entrained (mineral dust aerosols) and continuously transported into a deposition chamber placed on the snow surface where they deposit onto and into the snowpack, thereby modifying its surface reflectance and albedo. We demonstrate field operation of this apparatus by generating black and brown carbon combustion aerosols and entraining hematite mineral dust aerosol and depositing them on the snowpack. Changes in spectral snow reflectance are demonstrated qualitatively through pictures of snow surfaces after aerosol deposition and quantitatively by measuring hemispherical-conical reflectance spectra for the deposited areas and for adjacent snowpack in its natural state. Additional potential applications for this apparatus are mentioned and briefly discussed.
\end{abstract}

\section{Introduction}

Aerosols in the Earth-atmosphere system play a critical role in radiative forcing and climate change (IPCC, 2013). However, our understanding of how they affect the cryosphere upon deposition onto snow surfaces is still limited (Qian et al., 2015), particularly for aerosols other than black carbon (Skiles et al., 2018). Understanding aerosol-cryosphere interactions is important on several levels, including (1) the radiative properties of the snowpack modified by deposited aerosols (Warren and Wiscombe, 1980; Warren, 1982; Gard- ner and Sharp, 2010; Bond et al., 2013; Qian et al., 2015), which alter the seasonal timing of snowmelt, runoff, and water management (Painter et al., 2010; Dozier, 2011); (2) the relation between deposited nutrients and the snowpack biosphere (Thomas and Duval, 1995; Jones, 1999; Kuhn, 2001; Hodson et al., 2008); and (3) snowpack chemistry and photochemistry, which are influenced by the deposited chemical compounds and their interaction with solar radiation (Grannas et al., 2007). One limitation in our understanding is establishing links between theoretical and experimental results because it is difficult to experimentally characterize these interactions in a controlled manner; generally, aerosol deposition on snow is spatially and temporally very inhomogeneous, and often deposition and its immediate effects are minor. One scarcely used but effective experimental method is to artificially deposit aerosols of interest directly onto the snow surface.

Atmospheric deposition is an important process by which an exchange of nutrients, gasses, and particles takes place between the atmosphere and land and sea surfaces. Many deposition processes are irreversible; for example, once the deposition of particles occurs, the probability of re-entrainment is low. Atmospheric constituents are removed from the atmosphere through dry and wet deposition (Seinfeld and Pandis, 2016). Dry deposition is facilitated by gravitational settling, inertial impaction, and Brownian diffusion processes. Wet deposition, on the other hand, involves the scavenging of gasses and particles by clouds and precipitation through dissolution, cloud condensation nuclei (CCN) activity, and collision processes. Aerosol and gasses can enter into the ice-grain matrix of the snowpack through different means and alter chemical, physical, and radiative properties (Kuhn, 2001; Grannas et al., 2007). For snowpack radiative processes and energy balance, the deposition of light-absorbing 
aerosols (i.e., black carbon $(\mathrm{BC})$, brown carbon $(\mathrm{BrC})$, and mineral dust; Moosmüller et al., 2009) is of special interest because deposition of even minute quantities of strongly light-absorbing aerosols drastically increases the co-albedo of the snow surface in the visible and near-visible spectral regions, where pure snow is "snow white" with hardly any intrinsic absorption (Warren, 1982).

Carbonaceous aerosols in the atmosphere, including BC and $\mathrm{BrC}$ (Chakrabarty et al., 2010; Lack et al., 2014), are dominantly generated by incomplete combustion of fossil and biomass fuels with significant additional generation of secondary organic aerosols through oxidation of volatile precursors in the atmosphere (Bond et al., 2004; Lin et al., 2014). These aerosols are lofted into the atmosphere, where, during transport of a few days to weeks, they undergo secondary processing (Jimenez et al., 2009) and eventually are removed from the atmosphere through wet or dry deposition (Bond et al., 2013). BC is a ubiquitous light-absorbing aerosol in the atmosphere that directly affects Earth's radiative budget (Jacobson, 2001; Bond et al., 2013) and the cryosphere (Hegg et al., 2009; Flanner et al., 2009; Hadley and Kirchstetter, 2012; Qian et al., 2015). Recently, BrC has become of interest regarding its role in atmospheric light absorption (Laskin et al., 2015) and even more recently a topic of concern for affecting snow albedo and energy balance (Dang and Hegg, 2014; Doherty et al., 2014; Lin et al., 2014; Wu et al., 2016). The fraction of $\mathrm{BC}$ versus $\mathrm{BrC}$ mass emitted by combustion sources depends greatly on a number of factors, including fuel type, fuel moisture content, and packing density (Sumlin et al., 2018), combustion phase (Patterson and McMahon, 1984; Reid et al., 2005; Bond et al., 2004), and other elements of the system (Chen and Moosmüller, 2006). For BC, the imaginary part $\kappa$ of the refractive index is relatively large $(\kappa \approx 0.79)$ and varies little over the visible and near-visible wavelength regions (Bond et al., 2006; Moosmüller et al., 2009). Because the imaginary part of the refractive index is so high for $\mathrm{BC}$ relative to that of snow, a small amount of BC present in the snowpack significantly increases the co-albedo in those spectral regions (Warren and Wiscombe, 1980; Cereceda-Balic et al., 2018). For BrC, the imaginary refractive index of hematite is larger in the shorter visible wavelengths and near-UV (Chakrabarty et al., 2010; Moosmüller et al., 2009, 2011). Combustion systems - typically smoldering wildland fires - that produce a significant amount of $\mathrm{BrC}$ will have smoke plumes that are brownish or yellowish in appearance because of this spectral dependence (Andreae and Gelencsér, 2006). For this study, the boreal peat fuel used is the same as used by Sumlin et al. (2018), who found a value of $\kappa=0.014$ at $375 \mathrm{~nm}, \kappa=0.003$ at $532 \mathrm{~nm}$, and $\kappa=0.002$ at $1047 \mathrm{~nm}$. We are not aware of any published studies that explore the impact of deposition from a BrC-dominated emission source on snow or identify the spectral reflectance signature of $\mathrm{BrC}$ particles deposited onto snow.
In addition to the importance of carbonaceous aerosol deposition on snow, mineral dust deposition has been shown to be an important driver of early snowmelt in some mountains (e.g., Painter et al., 2007, 2012, 2018; Skiles et al., 2012). The light absorption of mineral dust is mostly caused by iron oxides, such as hematite $\left(\mathrm{Fe}_{2} \mathrm{O}_{3}\right)$ (Moosmüller et al., 2012; Zhang et al., 2015; Engelbrecht et al., 2016). Hematite is a mineral dust component with global-scale abundance and has been found to significantly absorb light in the ultraviolet (UV) and visible wavelengths - the imaginary refractive index of hematite is larger the shorter the visible wavelengths are and near $\mathrm{UV}(\kappa \approx 0.90$ at $460 \mathrm{~nm})$ and decreases with increasing wavelength (e.g., $\kappa \approx 0.035$ at $2500 \mathrm{~nm}$ ) (Querry, 1985; Moosmüller et al., 2009; Dubovik et al., 2002) - and may have the largest optically absorptive impact of all mineral dust components found in the cryosphere (Hegg et al., 2010). Mineral dust deposition on snow is a major concern for the albedo feedback effects in certain areas of the cryosphere (McConnell et al., 2007; Painter et al., 2007; Skiles et al., 2012; Zhou et al., 2017), and accurate experimental representation of dust depositions is critical to the understanding of their interaction with snow.

Previous experiments have utilized aerosol artificial deposition techniques to test non-natural snow surface albedo perturbations, but with varying success. Conway et al. (1996) manually mixed soot and volcanic ash with loose snow in a bucket before spreading it over a large plot. These methods were useful in understanding the characteristics and vertical location of aerosol during conditions of melt, but they likely restructured the bulk aerosol into agglomerations larger than what can be seen from normal deposition. Brandt et al. (2011) measured the snow albedo resulting from mixing commercially available soot into tap water and spraying the mixture through a commercially available snow-making machine over a field of artificial snowpack, produced with the same means. More recently, Peltoniemi et al. (2015) distributed chimney soot, glaciated silt, and volcanic sand onto the snow surface using a "salt shaker" in an attempt to measure the bidirectional reflectance factor of the resulting, contaminated snow. In addition, the snow albedo response to absorbing impurities on snow has been characterized by Singh et al. (2010) "spraying ... soil equally on the surface".

Our work presented here describes a simple apparatus to evenly deposit aerosols in an artificial manner onto a flat snow surface through dry deposition for the study of snow-aerosol interactions. Tests during the snow season of 2015-2016 were conducted at the Cold Regions Research and Engineering Laboratory-UC Santa Barbara Energy Site (CUES; Bair et al., 2018) on Mammoth Mountain, California, USA. During the 2016-2017 and 2017-2018 snow seasons, experiments were conducted at Tamarack Lake in the Carson Range of the Sierra Nevada in Nevada, USA. Controlled deposition experiments using the apparatus for hematite mineral dust entrainment and combustion aerosol 
production of $\mathrm{BC}$ and $\mathrm{BrC}$ to modify snow surface reflectance are presented as examples.

\section{Description and operation of apparatus}

The deposition apparatus presented here is composed of two primary components: the aerosol production or entrainment chamber and the deposition chamber. The materials used for the air source and production or entrainment chamber depend on the type of test aerosol generated or entrained and deposited onto the snow surface. The deposition chamber is the same for any type of aerosol used.

\subsection{Aerosol production chamber (combustion aerosols)}

A schematic diagram of the aerosol production chamber for generating combustion aerosols is shown in Fig. 1a. It consists of a flat plywood base with an area of $\sim 0.5 \mathrm{~m}^{2}$ and a $\sim 10 \mathrm{~L}$ near-cylindrical galvanized steel volume fitted with $\mathrm{a} \sim 1 \mathrm{~L}$ volume cone to its top; the cone funnels aerosols towards the chamber outlet. Inside the chamber, a $\sim 6 \mathrm{~cm}$ high stage is mounted on the plywood base, directly above a perforated inlet that disperses inlet air horizontally under the combustion stage. The bottom rim of the chamber is lined with a rubber seal that, when mounted to the plywood base with clamps, becomes near-airtight. The combustion stage can be adapted to house different combusting configurations to fit the user's needs; generally, it symmetrically distributes inlet air around the stage and serves as a platform for fuels to be burned. The air source used in the combustion aerosol configuration has three purposes: (1) to provide the appropriate amount of air for (incomplete) combustion to take place, (2) to provide continuous flow to move the combustion aerosols vertically (with assistance from flame buoyancy) through the production chamber towards the outlet, and (3) to create a pressure differential between the production chamber and the deposition chamber that ultimately moves aerosols from the production chamber to the deposition chamber and finally onto and into the snowpack. If the heat from the combustion source is too intense, a small amount of metal tubing arranged in a coil may be necessary to cool the combustion air before it is transported through any conducting rubber tubing, as shown in Fig. 3.

The air source used for this configuration is a batterypowered, $12 \mathrm{~V}$ air pump that provides inlet air into the entrainment chamber, with a flow rate of $\sim 5.3 \mathrm{~L} \mathrm{~min}^{-1}$ at the outlet of the production chamber. This outlet is connected to the deposition chamber mostly via $6 \mathrm{~mm}$ OD copper tubing, as rubber or plastic tubing near the production chamber may melt from the combustion heat.

The user of this apparatus can vary the mass of combustion material deposited by limiting the amount of time the fuel is combusting. Here, we purposefully produced heavy depo- sitions for optical inspection and verification of the proper operation of the apparatus.

\subsection{Aerosol entrainment chamber (mineral dust aerosols)}

For pulverized, dry solids such as mineral dusts, the entrainment chamber consists of a $1 \mathrm{~L}$ volume glass Büchner flask (e.g., Jensen, 2006), but it is used in an opposing manner, providing positive pressure rather than a vacuum. Here, the flask is filled with a generous amount $(\sim 90 \mathrm{~g})$ of the dust of interest; changing this amount allows for controlling the dust mass deposited onto the snow in the deposition chamber. Compressed air is introduced into the flask through the large opening at its top, sealed with a rubber stopper. The flask's short, horizontal tube acts as the outlet for entrained aerosols and is connected directly to the deposition chamber via conductive tubing. Dry solids are adequately resuspended using short, intense bursts of air typically between 200 and $300 \mathrm{kPa}$ in pressure from a hand-operated, positive-displacement piston pump, such as a common bike floor pump. A similar setup for the entrainment of mineral dust has previously been used by Moosmüller et al. (2012), Engelbrecht et al. (2016), and Piedra et al. (2018).

\subsection{Deposition chamber}

The deposition chamber for all aerosols is a near-cylindrical galvanized steel volume that measures approximately $50 \mathrm{~cm}$ in diameter at its midpoint and has a volume of $\sim 133 \mathrm{~L}$. This piece of the apparatus is shown in Fig. 2. There is an inlet at the top of the volume that allows for aerosol flow from the production or entrainment chamber and disperses the aerosols into the volume by splitting the aerosol flow into three separate outflows symmetrical about the center of the chamber, for uniform aerosol deposition onto the snow surface. There is no exhaust or outlet for air entering the deposition chamber besides through the snowpack, and the flow rate of air entering the deposition chamber may vary. The design of the instrument is to pump aerosol into the snow, and the depth of particle capture by the snowpack depends on a variety of issues, as discussed in Kuhn (2001) and references therein.

Previous implementations of the apparatus included a $90 \mathrm{~mm}$ diameter, $12 \mathrm{~V} \mathrm{DC}$-powered fan that was thought to help facilitate the dispersion of particles within the deposition chamber. This battery-powered fan was mounted in the approximate centroid of the chamber and was tested in several different flow directions. Figure $4 \mathrm{a}$ and $\mathrm{b}$ represent depositions of hematite while using this fan in the deposition chamber to test for increased deposition uniformity. However, the presence of the fan created less uniform depositions, so the fan was removed. Figure $4 \mathrm{c}$ shows a deposition of hematite with the most up-to-date configuration of the deposition apparatus, without the fan. 


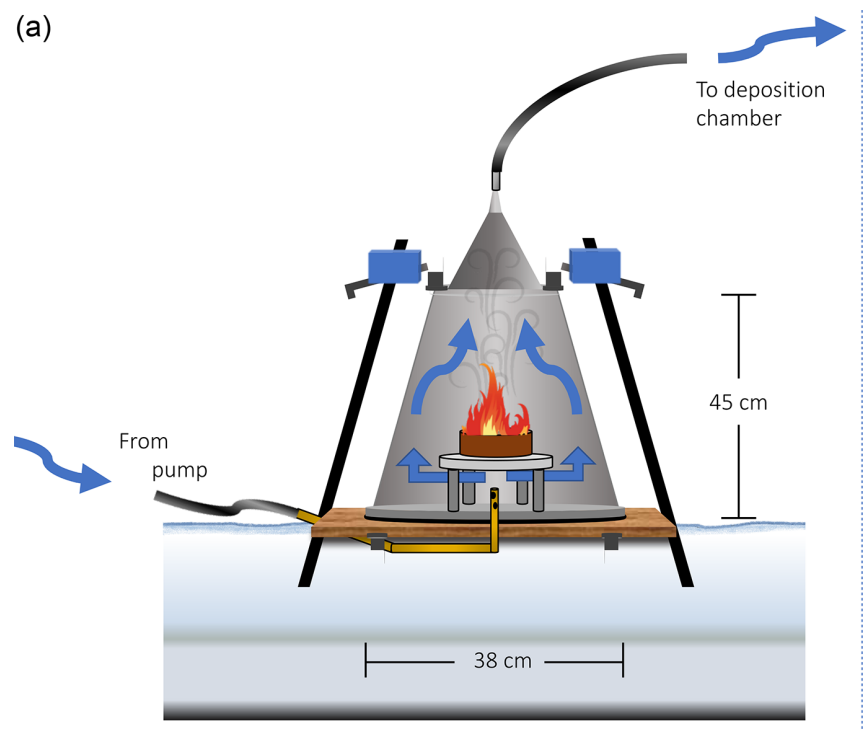

(b)

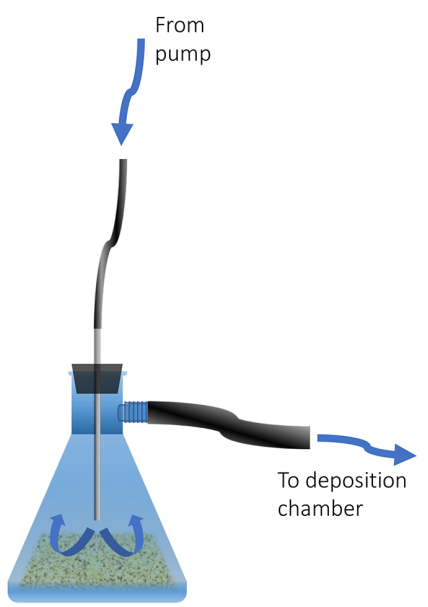

Figure 1. A battery-powered pump provided combustion and transport air into the aerosol production chamber for combustion aerosol (a), which flows to the deposition chamber at a flow rate of $\sim 5.3 \mathrm{~L} \mathrm{~min}^{-1}$. A $1 \mathrm{~L}$ glass Büchner flask was used as the entrainment chamber for dry, pulverized dusts (b), which was provided short, quick bursts of air from a positive-displacement piston pump. The schematics are not drawn to scale.

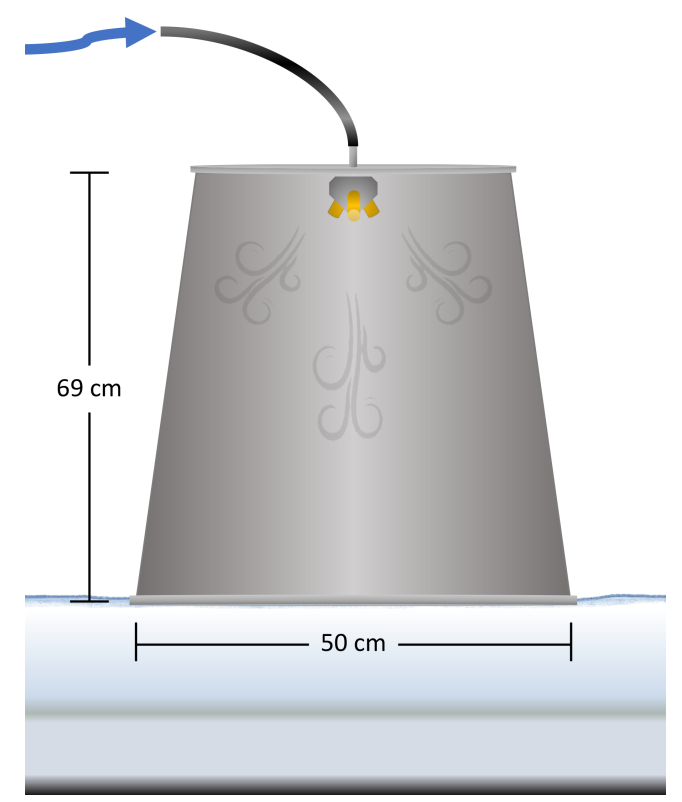

Figure 2. The deposition chamber for all aerosol types consists of a near-cylindrical volume with aerosols pumped into the inlet at the top of the chamber from the production or entrainment chamber. The deposited area measures approximately $0.20 \mathrm{~m}^{2}$.

\section{Characterization of apparatus and results}

To demonstrate the effectiveness of this deposition apparatus, it was tested during the spring of the 2016, 2017, and 2018. Deposition of three different aerosol types was demonstrated: $\mathrm{BC}$ and $\mathrm{BrC}$ in the combustion aerosol produc-

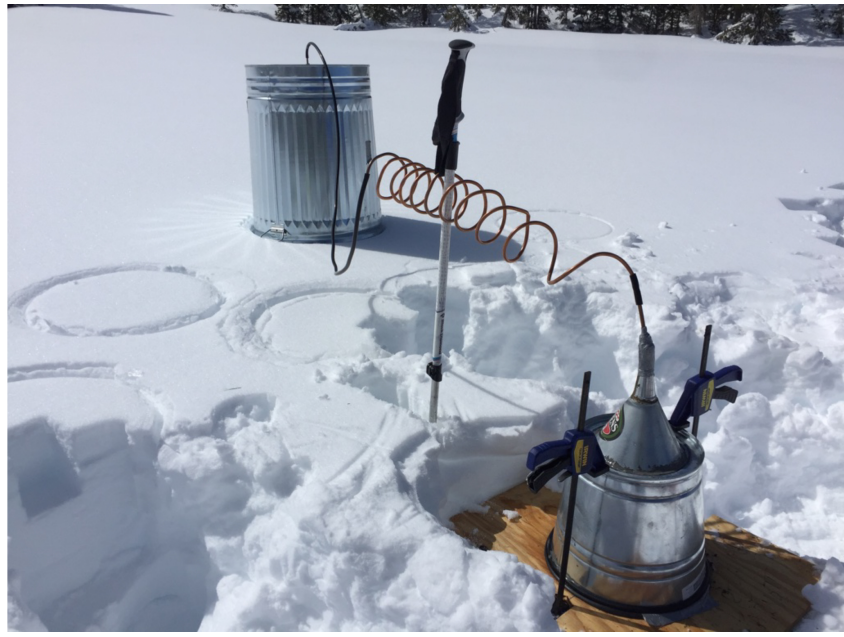

Figure 3. Use of the apparatus at the Tamarack Lake site for depositing $\mathrm{BC}$ aerosol.

tion configuration and a dry, sieved mineral dust, hematite $\left(\mathrm{Fe}_{2} \mathrm{O}_{3}\right)$, to test the entrainment configuration. Information regarding the size distribution of each tested aerosol can be found in the Supplement accompanying this paper. Hematite deposition was tested at the Cold Regions Research and Engineering Laboratory-UC Santa Barbara Energy Site (CUES; Bair et al., 2018) on Mammoth Mountain, California $\left(37^{\circ} 38^{\prime} 35.19^{\prime \prime} \mathrm{N}, 119^{\circ} 1^{\prime} 44.97^{\prime \prime} \mathrm{W} ; 2940 \mathrm{~m}\right.$ a.s.1.), on 11 May 2016. BrC and $\mathrm{BC}$ deposition was tested in the Carson Range of the Sierra Nevada at Tamarack Lake, $\mathrm{NV}\left(39^{\circ} 19^{\prime} 2.517^{\prime \prime} \mathrm{N}, 119^{\circ} 54^{\prime} 19.512^{\prime \prime} \mathrm{W} ; 2694 \mathrm{~m}\right.$ a.s.1.), on 


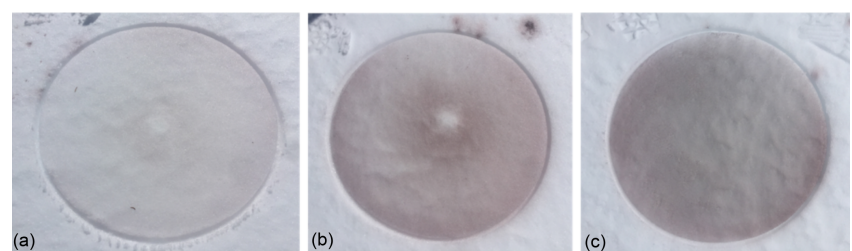

Figure 4. Images of three hematite depositions allow for visual inspection of the deposition uniformity. Panels (a) and (b) represent a previous apparatus design which featured a fan mounted inside the deposition chamber, which created less uniform depositions. Panel (c) represents a hematite deposition using the final configuration of the apparatus.

2 May 2017 and 24 April 2018, respectively; the lake was frozen and covered by snow deposited on its ice surface, creating a flat, homogeneous natural snowpack that is ideal for testing this apparatus.

To quantify the effect of aerosol deposition onto a natural snow surface, both subjective and objective measures were used. The uniformity of the aerosol deposition was inspected visually for aerosol types that are visually dark, or optically absorbing, as for the hematite deposition in Fig. 4. In addition, the hemispherical-conical reflectance factor (HCRF; Schaepman-Strub et al., 2006) was measured with an Analytical Spectral Devices (ASD) FieldSpec3 spectroradiometer to verify that aerosol was indeed altering the surface spectral reflectivity of the snow and to spectrally quantify that effect. Note that the measured HCRF is related to the surface albedo, controlling solar energy input to the snowpack (Schaepman-Strub et al., 2006). After deposition of the different aerosol species, HCRF was measured for the deposition area as well as for an adjacent, untreated, natural surface that mirrored the snow properties of the deposition area prior to the experiment. This allowed the characterization and verification of the snow reflectivity reduction due to aerosol deposition. A total of 10 measurements of HCRF were performed and averaged for each deposition area. This averaged value is presented throughout this paper with 1 standard deviation of the mean.

Measurement information and environmental conditions are summarized in Table 1. Solar zenith and azimuth angles have been obtained from the date and time of the measurement using the NOAA ESRL Solar Position Calculator (https://www.esrl.noaa.gov/gmd/grad/solcalc/azel.html, last access: 17 December 2018). The spectrometer optical input is a cone from the instrument's bare optical fiber with fullangle field of view of $25^{\circ}$; all observation angles are nadir within a few degrees. Meteorological information was obtained for the Tamarack Lake site from the nearby NRCS SNOTEL site at Mt. Rose (2683 m a.s.l.; https://wcc.sc.egov. usda.gov/nwcc/site?sitenum=652, last access: 17 December 2018) and for the CUES site from its meteorological in- strumentation (http://snow.ucsb.edu/, last access: 17 December 2018).

\subsection{Example: combustion aerosol deposition}

\subsubsection{Black carbon (BC) deposition}

Generation and deposition of $\mathrm{BC}$ aerosol took place during the spring of 2018 at Tamarack Lake. A kerosene lamp was used to produce BC aerosol (Arnott et al., 2000; Arnold et al., 2014) to be deposited onto the snow surface. First, the $12 \mathrm{~V}$ pump was started to begin moving air through the complete apparatus and provide enough air to sustain the combustion; without this forced air, the flame would quickly be extinguished due to lack of oxidant. The kerosene lamp was filled with fuel and lit before being placed onto the combustion stage and the production chamber being sealed with clamps. Then, the deposition chamber was lowered onto the desired snow surface, thereby initiating $\mathrm{BC}$ deposition on the snow. For this experiment, the kerosene lamp was ignited, and aerosol emissions were pumped into the deposition chamber for $45 \mathrm{~min}$. After this time, the flame was extinguished manually, and air was pumped through the apparatus for an additional $15 \mathrm{~min}$ to facilitate further deposition of aerosol onto and into the snowpack. The deposition chamber was promptly removed, and spectral reflection properties of the deposited and nearby unsoiled snow surfaces were characterized with HCRF measurements.

This deposition of BC aerosol reduced the HCRF from $\sim 0.87 \pm 0.003$ to $\sim 0.65 \pm 0.019$ at $500 \mathrm{~nm}$, an approximate reduction of $\sim 22 \%$ corresponding to a large increase ( $\sim$ factor of 2.5-3) of the solar energy input to the snowpack. An image of the deposition area is presented in Fig. 5, along with corresponding HCRF measurements made for the deposition area and for adjacent natural snow. Of the example depositions presented, this deposition was the least uniform.

\subsubsection{Brown carbon $(\mathrm{BrC})$ deposition}

The fuel combusted for $\mathrm{BrC}$ aerosol generation consisted of boreal peat samples collected from interior Alaska, USA. Details of this fuel - including its collection and preparation - have been given by Chakrabarty et al. (2016). The optical, physical, and chemical properties of aerosol emissions from combustion of this fuel have been extensively studied to evaluate the impact of its combustion emissions on air quality and radiative forcing in the atmosphere through optical, physical, and chemical characterization (Chakrabarty et al., 2016; Samburova et al., 2016; Sengupta et al., 2018; Sumlin et al., 2017, 2018). Prior to combustion, the fuel samples were placed into a round, insulated container to mimic simple, real-world conditions in which there is little lateral heat flux due to largely homogeneous horizontal conditions. The fuel samples were burning with nearly exclusively smoldering phase combustion, producing OC-rich biomass burn- 
Table 1. Overview of deposition and HCRF collection information.

\begin{tabular}{llrlrrr}
\hline Site & Deposited aerosol & $\begin{array}{r}\text { Altitude } \\
(\mathrm{m})\end{array}$ & $\begin{array}{l}\text { Date of } \\
\text { experiment }\end{array}$ & $\begin{array}{r}\mathrm{SZ}^{\mathrm{a}} \\
\left({ }^{\circ}\right)\end{array}$ & $\begin{array}{r}\mathrm{AZ}^{\mathrm{b}} \\
\left({ }^{\circ}\right)\end{array}$ & $\begin{array}{r}\text { Avg. air } \\
\text { temp. }\end{array}$ \\
\hline CUES, CA, USA & $\left.{ }^{\circ} \mathrm{C}\right)$ \\
Tamarack Lake, NV, USA & Bematite $\left(\mathrm{Fe}_{2} \mathrm{O}_{3}\right)$ & 2940 & 10 May 2016 & 21.5 & 154.3 & 8.4 \\
Tamarack Lake, NV, USA & Black Carbon $(\mathrm{BC})$ & 2694 & 24 Apr 2018 & 26.7 & 167.6 & 10.4 \\
\hline
\end{tabular}

a SZ: solar zenith angle at time of HCRF data collection. ${ }^{\mathrm{b}}$ AZ: solar azimuth angle at time of HCRF data collection. ${ }^{\mathrm{c}}$ Average temperature during the HCRF data collection period. For the Tamarack Lake site, values are taken from the Mt. Rose NRCS SNOTEL site, which lies $0.9 \mathrm{~km}$ southeast at $2683 \mathrm{~m}$ in altitude. For the CUES site, these are taken directly from the CUES meteorological instrumentation.
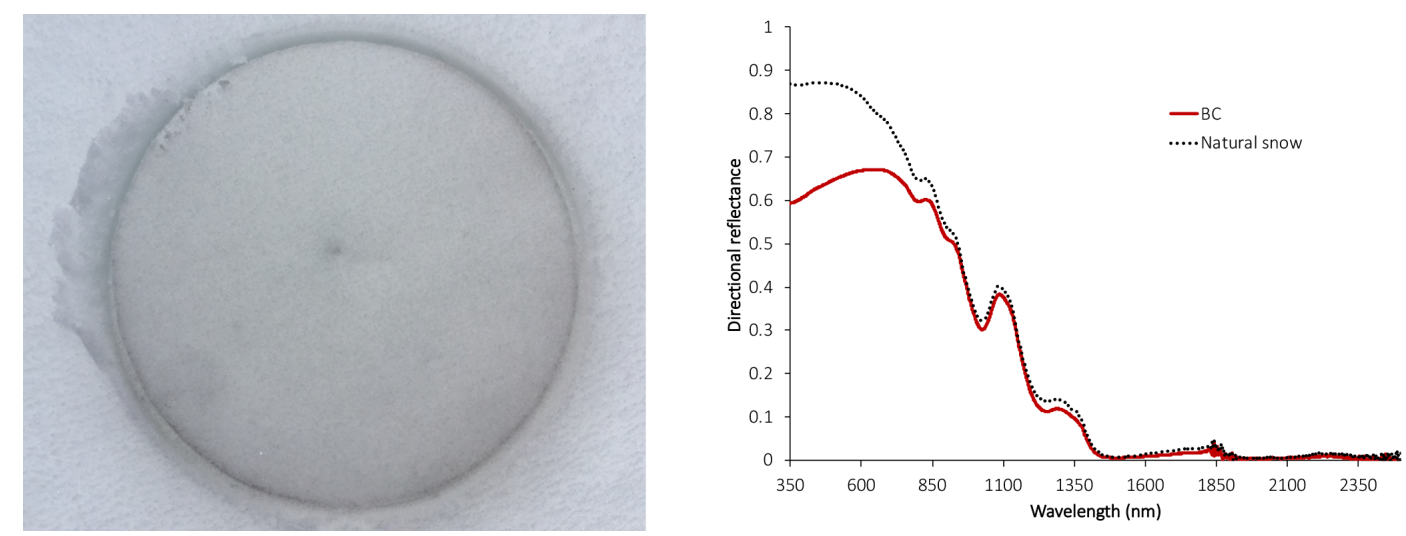

Figure 5. Image and HCRF spectra for a BC deposition and adjacent natural snow in April 2018 at the Tamarack Lake site. This BC deposition drastically reduced the high natural snow reflectivity in the visible and near-visible spectral regions. Solar zenith: $26.7^{\circ}$; solar azimuth: $167.6^{\circ}$.

ing aerosols. The fuel samples were smoldering for $\sim 30$ $40 \mathrm{~min}$; after this period, we continued to pump air through the apparatus for an additional 15 min to facilitate further deposition of aerosol onto and into the snowpack. Following the deposition, the deposition chamber was removed and HCRF measurements were made on the deposited and nearby undisturbed snow surfaces.

$\mathrm{BrC}$ deposited onto the snow surface greatly reduced the measured HCRF, but only at the shorter visible and UV wavelengths. The effect presented here reduced the reflectivity of a springtime snowpack from $0.92 \pm 0.003$ for the adjacent natural snowpack to $0.53 \pm 0.02$ at $350 \mathrm{~nm}$, a reduction of $\sim 39 \%$ for the $\mathrm{BrC}$ deposited snow. The resulting image and spectrum are presented in Fig. 6. The image of the deposition clearly shows a yellowish appearance, an indication of BrC's preferential absorption of blue wavelengths. This visual impression and the corresponding spectrum (Fig. 6), confirms the dominance of $\mathrm{BrC}$ over $\mathrm{BC}$ aerosol within the snowpack, as BC would have reduced snow reflectivity across the visible and near-visible spectrum and resulted in a greyish or blackish appearance on the snow surface.

\subsection{Example: deposition of resuspended mineral dust - hematite}

Mineral dust in the atmosphere - and that deposited into the cryosphere - has varying optical properties depending on its chemical and mineralogical composition. Here, synthetically made, pure hematite $\left(\mathrm{Fe}_{2} \mathrm{O}_{3}\right)$ was used as a surrogate for strongly absorbing, red-colored mineral dust with high iron oxide and hematite content. Depositions of hematite were made on a relatively level, undisturbed snow surface at the CUES research site.

A generous amount - approximately $90 \mathrm{~g}$ - of hematite dust was placed into the Büchner flask and was entrained and pumped into the deposition chamber as described in Sect. 2. The dust was allowed to gravitationally settle onto the snow surface for approximately $30 \mathrm{~min}$, at which time the deposition chamber was removed and HCRF measurements were made for the deposited snow surface and the adjacent natural snow. The resulting image and spectrum from this test are shown in Fig. 7. The resulting HCRF was reduced by approximately $35 \%$ in the $350-575 \mathrm{~nm}$ wavelength range when compared to that of the nearby natural snowpack. 

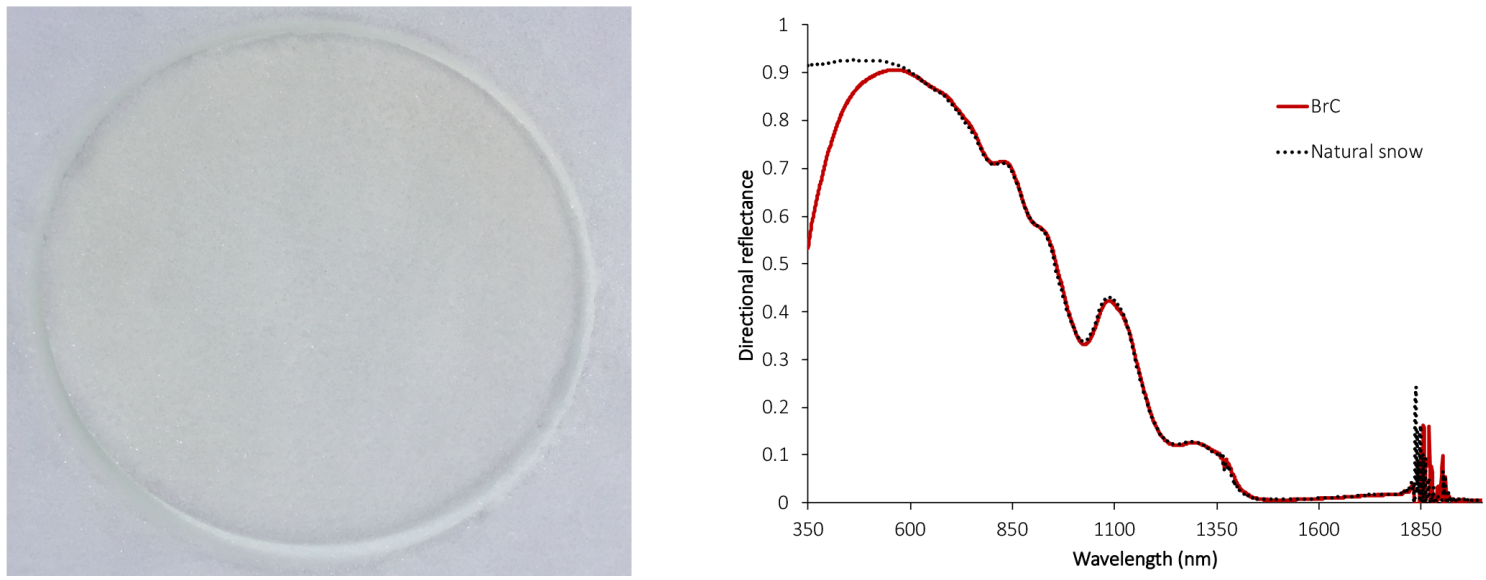

Figure 6. Image and HCRF spectra for a BrC deposition and adjacent natural snow in May 2017 at the Tamarack Lake site. This BrC deposition drastically reduced the high natural snow reflectivity in the ultraviolet and short-wavelength visible $(<500 \mathrm{~nm})$ spectral regions. Solar zenith: $34.6^{\circ}$; solar azimuth: $235.0^{\circ}$.
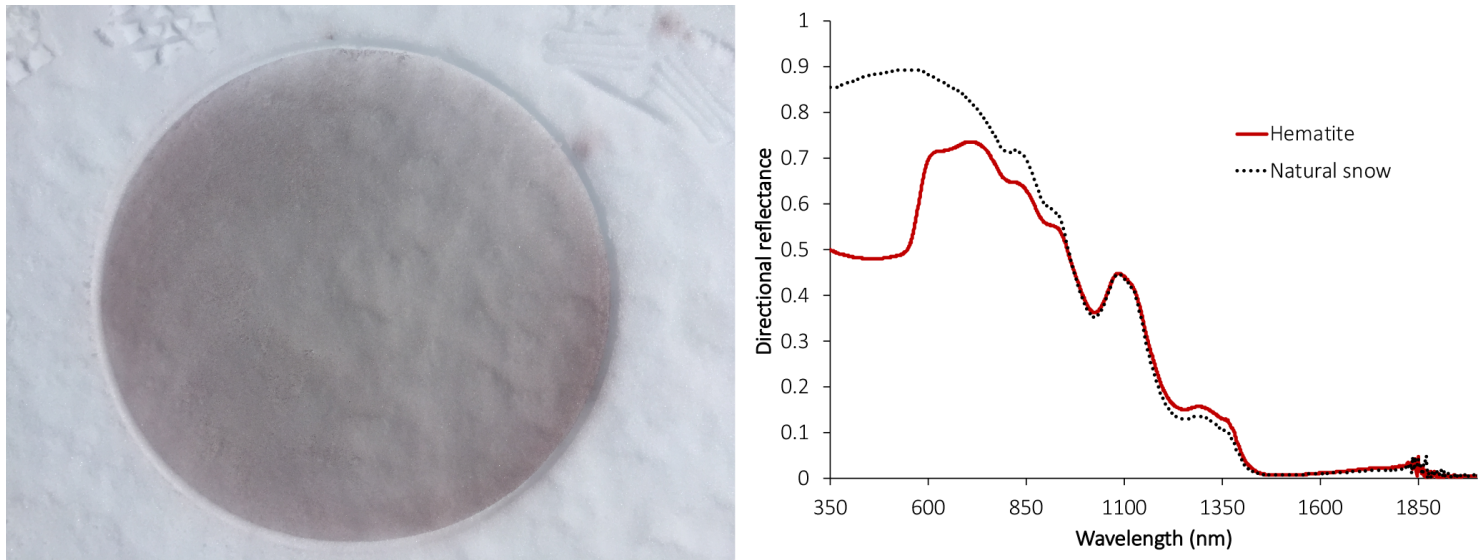

Figure 7. Image and HCRF spectra for a hematite deposition and adjacent natural snow in May 2016 at the CUES research site. This hematite deposition drastically reduced the high natural snow reflectivity in the ultraviolet and short-wavelength visible $(<600 \mathrm{~nm})$ spectral regions. Solar zenith: $21.5^{\circ}$; solar azimuth: $154.3^{\circ}$.

\subsection{Challenges and further development}

The apparatus described here is not perfect but a work in progress and will benefit from further development by us and others. Some of the limitations and potential biases are outlined below.

A substantial but not quantified fraction of the aerosols generated in the production or entrainment chamber is lost during transport and deposited on walls and tubing, as evidenced by the surfaces of the apparatus darkening and acquiring a typical smell for $\mathrm{BrC}$ depositions. Additionally, the authors made no effort to monitor the mass of deposited material or how deep the aerosol penetrated into the snowpack; instead, they leave this issue for future development. Particle deposition onto the snow is not perfectly homogenous and this homogeneity varies from deposition to deposition. The dominant factor controlling homogeneity of the deposit seems to be wind, which causes the deposition to favor the lee side of the deposition area due to the air's ability to permeate and travel through the snowpack (e.g., Waddington et al., 1996). Additionally, this apparatus may alter the grain size of snow located at the top of the snowpack due to heating of the air inside the deposition chamber. Monitoring the grain size of surrounding natural snow and comparing it to that of grains within the deposition area after the experiment can shed light on the induced effects. By conducting this analysis using the methods outlined in Nolin and Dozier (2000), we have concluded that, for this set of experiments, there is no consistent change in grain size. Temperature artifacts in the deposition chamber could partly be mitigated by painting the exterior surface white to better reflect incident solar radiation.

Ensuring identical conditions inside and outside of the deposition chamber would be very challenging. Additional in- 
strumentation within the deposition chamber can help quantify the impact that outside air temperature, incoming solar radiation, outgoing thermal infrared radiation, and wind speed could have on experimentation. Perhaps the use of an identical deposition chamber, one with and one without introduced aerosols, could minimize this problem.

\section{Conclusion and discussion}

The apparatus described here provides a means to generate or entrain and to artificially deposit aerosols evenly onto a snow surface. The apparatus has been proven to efficiently deposit carbonaceous aerosols - $\mathrm{BC}$ and $\mathrm{BrC}$ - from two combustion sources as well as entrained dry mineral dust onto snow, thereby altering the surface reflectivity of snow. The reduction of spectral surface reflectivity was verified by measuring the directional surface reflectance within the area of deposition and comparing it to the reflectance of neighboring natural snow. To the best of the authors' knowledge, this study is the first to deposit primary aerosol from combustion sources in situ, which provides the user of the apparatus with a novel tool to investigate the impact that these prolific snow impurities have after deposition. This investigation has proven that future applications of this apparatus are numerous.

The type of aerosol being deposited, the total mass of that aerosol, and the environmental conditions surrounding the deposition area can be adjusted by the users to suit their needs. The methods outlined by Skiles et al. (2017) to retrieve the refractive index of deposited aerosols from directional reflectance measurements can be applied to the artificial deposition methods described here with some additional radiative transfer analysis. Similarly, one can apply this apparatus to the testing of snow radiative transfer codes (e.g., SNICAR, Flanner and Zender, 2005; TARTES, Libois et al., 2013) as to their treatment of the influence of impurities deposited onto the snowpack. Beres et al. (2019) deposit varying concentrations of $\mathrm{BrC}$ onto the snow surface and verify measured total organic carbon concentrations for their albedo-reducing effect in an aerosol-snow coupled radiative transfer model.

The growing importance of understanding the link between radiative forcing by a variety of aerosols found in the atmosphere and their relationship to the change in physical, chemical, and optical properties of snow and ice are a field that can utilize this apparatus in the future. $\mathrm{BrC}$ aerosols have an impact on the cryosphere that is not well understood but potentially important, based on the close proximity of BrC-rich fuel sources to snow and ice surfaces and the proclivity of wildfires in the boreal forests of the northern latitudes (Flannigan et al., 2009; Oris et al., 2014; Beres et al., 2019). Additionally, the increased emissions of dusts across the globe (Mahowald et al., 2010) and their impact on snow radiative forcing can benefit from this device. For example, one could entrain other globally important dusts, such as those found in Engelbrecht et al. (2016), using this apparatus. While the first implementation of any new apparatus is imperfect, its usefulness and importance for the cryosphere sciences is obvious.

Data availability. The authors provide the numerical values of HCRF spectra shown in figures within the paper in the Supplement. Additionally, the authors have provided normalized, laboratorymeasured size distributions that correspond to aerosols produced for this study under similar conditions.

Supplement. The supplement related to this article is available online at: https://doi.org/10.5194/amt-11-6803-2018-supplement.

Author contributions. NDB and HM contributed approximately equally to all parts of this publication.

Competing interests. The authors declare that they have no conflict of interest.

Acknowledgements. This material has been supported in part by NASA EPSCoR under Cooperative Agreement no. NNX14AN24A, NASA ROSES under grant no. NNX15AI48G, and by the National Science Foundation under grant no. AGS-1544425. It is a pleasure to acknowledge Deep Sengupta for help with field experiments, Adam Watts for supplying the peat samples, and Jeff Dozier, Ned Bair, and Mammoth Mountain Ski Resort for generously providing access to and assistance at CUES.

Edited by: Manfred Wendisch

Reviewed by: Jeff Dozier and one anonymous referee

\section{References}

Andreae, M. O. and Gelencsér, A.: Black carbon or brown carbon? The nature of light-absorbing carbonaceous aerosols, Atmos. Chem. Phys., 6, 3131-3148, https://doi.org/10.5194/acp-63131-2006, 2006.

Arnold, I. J., Berger, C., Chakrabarty, R. K., Moosmüller, H., Sharma, N., and Mazzoleni, C.: The iron lung: A device for the continuous delivery of fine particulate matter, Rev. Sci. Instrum., 85, 25105, https://doi.org/10.1063/1.4865114, 2014.

Arnott, W. P., Moosmuüller, H., and Walker, J. W.: Nitrogen dioxide and kerosene-flame soot calibration of photoacoustic instruments for measurement of light absorption by aerosols, Rev. Sci. Instrum., 71, 4545, https://doi.org/10.1063/1.1322585, 2000.

Bair, E. H., Davis, R. E., and Dozier, J.: Hourly mass and snow energy balance measurements from Mammoth Mountain, CA USA, 2011-2017, Earth Syst. Sci. Data, 10, 549-563, https://doi.org/10.5194/essd-10-549-2018, 2018.

Beres, N. D., Sengupta, D., Samburova, V., Painter, T. H., and Moosmüller, H.: Brown Carbon on snow: reduction of spectral 
albedo and its implications, Atmos. Chem. Phys., in preparation, 2019.

Bond, T. C. and Bergstrom, R. W.: Light absorption by carbonaceous particles: an investigative review, Aerosol Sci. Technol., 40, 27-67, https://doi.org/10.1080/02786820500421521, 2006.

Bond, T. C., Streets, D. G., Yarber, K. F., Nelson, S. M., Woo, J.-H., and Klimont, Z.: A technology-based global inventory of black and organic carbon emissions from combustion, J. Geophys. Res., 109, D14203, https://doi.org/10.1029/2003JD003697, 2004.

Bond, T. C., Doherty, S. J., Fahey, D. W., Forster, P. M., Berntsen, T., DeAngelo, B. J., Flanner, M. G., Ghan, S., Kärcher, B., Koch, D., Kinne, S., Kondo, Y., Quinn, P. K., Sarofim, M. C., Schultz, M. G., Schulz, M., Venkataraman, C., Zhang, H., Zhang, S., Bellouin, N., Guttikunda, S. K., Hopke, P. K., Jacobson, M. Z., Kaiser, J. W., Klimont, Z., Lohmann, U., Schwarz, J. P., Shindell, D., Storelvmo, T., Warren, S. G., and Zender, C. S.: Bounding the role of black carbon in the climate system: A scientific assessment, J. Geophys. Res.-Atmos., 118, 5380-5552, https://doi.org/10.1002/jgrd.50171, 2013.

Brandt, R. E., Warren, S. G., and Clarke, A. D.: A controlled snowmaking experiment testing the relation between black carbon content and reduction of snow albedo, J. Geophys. Res., 116, D08109, https://doi.org/10.1029/2010JD015330, 2011.

Cereceda-Balic, F., Vidal, V., Moosmüller, H., and Lapuerta, M.: Reduction of snow albedo from vehicle emissions at Portillo, Chile, Cold Reg. Sci. Technol., 146, 43-52, https://doi.org/10.1016/j.coldregions.2017.11.008, 2018.

Chakrabarty, R. K., Moosmüller, H., Chen, L.-W. A., Lewis, K., Arnott, W. P., Mazzoleni, C., Dubey, M. K., Wold, C. E., Hao, W. M., and Kreidenweis, S. M.: Brown carbon in tar balls from smoldering biomass combustion, Atmos. Chem. Phys., 10, 63636370, https://doi.org/10.5194/acp-10-6363-2010, 2010.

Chakrabarty, R. K., Gyawali, M., Yatavelli, R. L. N., Pandey, A., Watts, A. C., Knue, J., Chen, L.-W. A., Pattison, R. R., Tsibart, A., Samburova, V., and Moosmüller, H.: Brown carbon aerosols from burning of boreal peatlands: microphysical properties, emission factors, and implications for direct radiative forcing, Atmos. Chem. Phys., 16, 3033-3040, https://doi.org/10.5194/acp-16-3033-2016, 2016.

Conway, H., Gades, A., and Raymond, C. F.: Albedo of dirty snow during conditions of melt, Water Resour. Res., 32, 1713-1718, https://doi.org/10.1029/96WR00712, 1996.

Dang, C. and Hegg, D. A.: Quantifying light absorption by organic carbon in Western North American snow by serial chemical extractions, J. Geophys. Res.-Atmos., 119, 10247-10261, https://doi.org/10.1002/2014JD022156, 2014.

Doherty, S. J., Dang, C., Hegg, D. A., Zhang, R., and Warren, S. G.: Black carbon and other light-absorbing particles in snow of central North America, J. Geophys. Res.-Atmos., 119, 1280712831, https://doi.org/10.1002/2014JD022350, 2014.

Dozier, J.: Mountain hydrology, snow color, and the fourth paradigm, Eos, T. Am. Geophys. Union, 92, 373-374, https://doi.org/10.1029/2011EO430001, 2011.

Dubovik, O., Holben, B., Eck, T. F., Smirnov, A., Kaufman, Y. J., King, M. D., Tanré, D., and Slutsker, I.: Variability of absorption and optical properties of key aerosol types observed in worldwide locations, J. At- mos. Sci., 59, 590-608, https://doi.org/10.1175/1520 0469(2002)059<0590:VOAAOP>2.0.CO;2, 2002.

Engelbrecht, J. P., Moosmüller, H., Pincock, S., Jayanty, R. K. M., Lersch, T., and Casuccio, G.: Technical note: Mineralogical, chemical, morphological, and optical interrelationships of mineral dust re-suspensions, Atmos. Chem. Phys., 16, 10809-10830, https://doi.org/10.5194/acp-16-10809-2016, 2016.

Flanner, M. G. and Zender, C. S.: Snowpack radiative heating: Influence on Tibetan Plateau climate, Geophys. Res. Lett., 32, L06501, https://doi.org/10.1029/2004GL022076, 2005.

Flanner, M. G., Zender, C. S., Hess, P. G., Mahowald, N. M., Painter, T. H., Ramanathan, V., and Rasch, P. J.: Springtime warming and reduced snow cover from carbonaceous particles, Atmos. Chem. Phys., 9, 2481-2497, https://doi.org/10.5194/acp9-2481-2009, 2009.

Flannigan, M., Stocks, B., Turetsky, M., and Wotton, M.: Impacts of climate change on fire activity and fire management in the circumboreal forest, Glob. Change Biol., 15, 549-560, https://doi.org/10.1111/j.1365-2486.2008.01660.x, 2009.

Gardner, A. S. and Sharp, M. J.: A review of snow and ice albedo and the development of a new physically based broadband albedo parameterization, J. Geophys. Res.-Earth, 115, 115, https://doi.org/10.1029/2009JF001444, 2010.

Grannas, A. M., Jones, A. E., Dibb, J., Ammann, M., Anastasio, C., Beine, H. J., Bergin, M., Bottenheim, J., Boxe, C. S., Carver, G. Chen, G., Crawford, J. H., Domine, F., Frey, M. M., Guzman, M. I., Heard, D. E., Helmig, D., Hoffmann, M. R., Honrath, R. E., Huey, L. G., Hutterli, M., Jacobi, H. W., Klan, P., Lefer, B., McConnell, J., Plane, J., Sander, R., Savarino, J., Shepson, P. B., Simpson, W. R., Sodeau, J. R., von Glasow, R., Weller, R., Wolff, E. W., and Zhu, T.: An overview of snow photochemistry: evidence, mechanisms and impacts, Atmos. Chem. Phys, 7, 43294373, https://doi.org/10.5194/acp-7-4329-2007, 2007.

Hadley, O. L. and Kirchstetter, T. W.: Black-carbon reduction of snow albedo, Nat. Clim. Change, 2, 437-440, https://doi.org/10.1038/nclimate1433, 2012.

Hegg, D. A., Warren, S. G., Grenfell, T. C., Doherty, S. J., Larson, T. V., and Clarke, A. D.: Source attribution of black carbon in Arctic snow, Environ. Sci. Technol., 43, 4016-4021, https://doi.org/10.1021/es803623f, 2009.

Hegg, D. A., Warren, S. G., Grenfell, T. C., Doherty, S. J., and Clarke, A. D.: Sources of light-absorbing aerosol in arctic snow and their seasonal variation, Atmos. Chem. Phys., 10, 1092310938, https://doi.org/10.5194/acp-10-10923-2010, 2010.

Hodson, A., Anesio, A. M., Tranter, M., Fountain, A., Osborn, M., Priscu, J., Laybourn-Parry, J., and Sattler, B.: Glacial ecosystems, Ecol. Monogr., 78, 41-67, https://doi.org/10.1890/07-0187.1, 2008.

IPCC, 2013: Climate Change 2013: The Physical Science Basis. Contribution ofWorking Group I to the Fifth Assessment Report 95 of the Intergovernmental Panel on Climate Change, edited by: Stocker, T. F., Qin, D., Plattner, G.-K., Tignor, M., Allen, S. K., Boschung, J., Nauels, A., Xia, Y., Bex, V., and Midgley, P. M., Cambridge University Press, Cambridge, UK and New York, NY, USA, https://doi.org/10.1017/CBO9781107415324, 2013.

Jacobson, M. Z.: Strong radiative heating due to the mixing state of black carbon in atmospheric aerosols, Nature, 409, 695-697, https://doi.org/10.1038/35055518, 2001. 
Jensen, W. B.: The Origins of the Hirsch and Büchner vacuum filtration funnels, J. Chem. Educ., 83, 1283, https://doi.org/10.1021/ed083p1283, 2006.

Jimenez, J. L., Canagaratna, M. R., Donahue, N. M., Prevot, A. S. H., Zhang, Q., Kroll, J. H., DeCarlo, P. F., Allan, J. D., Coe, H., Ng, N. L., Aiken, A. C., Docherty, K. S., Ulbrich, I. M., Grieshop, A. P., Robinson, A. L., Duplissy, J., Smith, J. D., Wilson, K. R., Lanz, V. A., Hueglin, C., Sun, Y. L., Tian, J., Laaksonen, A., Raatikainen, T., Rautiainen, J., Vaattovaara, P., Ehn, M., Kulmala, M., Tomlinson, J. M., Collins, D. R., Cubison, M. J., Dunlea, J., Huffman, J. A., Onasch, T. B., Alfarra, M. R., Williams, P. I., Bower, K., Kondo, Y., Schneider, J., Drewnick, F., Borrmann, S., Weimer, S., Demerjian, K., Salcedo, D., Cottrell, L., Griffin, R., Takami, A., Miyoshi, T., Hatakeyama, S., Shimono, A., Sun, J. Y., Zhang, Y. M., Dzepina, K., Kimmel, J. R., Sueper, D., Jayne, J. T., Herndon, S. C., Trimborn, A. M., Williams, L. R., Wood, E. C., Middlebrook, A. M., Kolb, C. E., Baltensperger, U., and Worsnop, D. R.: Evolution of Organic Aerosols in the Atmosphere, Science, 326, 1525-1529, https://doi.org/10.1126/science.1180353, 2009.

Jones, H. G.: The ecology of snow-covered systems: a brief overview of nutrient cycling and life in the cold, Hydrol. Proc., 13, 2135-2147, https://doi.org/10.1002/(SICI)1099 1085(199910)13:14/15<2135::AID-HYP862>3.3.CO;2-P, 1999.

Kuhn, M.: The nutrient cycle through snow and ice, a review, Aquat. Sci., 63, 150-167, https://doi.org/10.1007/PL00001348, 2001.

Lack, D. A., Moosmüller, H., McMeeking, G. R., Chakrabarty, R. K., and Baumgardner, D.: Characterizing elemental, equivalent black, and refractory black carbon aerosol particles: a review of techniques, their limitations and uncertainties, Anal. Bioanal. Chem., 406, 99-122, https://doi.org/10.1007/s00216-013-74023, 2014.

Laskin, A., Laskin, J., and Nizkorodov, S. A.: Chemistry of atmospheric brown carbon, Chem. Rev., 115, 4335-4382, https://doi.org/10.1021/cr5006167, 2015.

Libois, Q., Picard, G., France, J. L., Arnaud, L., Dumont, M., Carmagnola, C. M., and King, M. D.: Influence of grain shape on light penetration in snow, The Cryosphere, 7, 1803-1818, https://doi.org/10.5194/tc-7-1803-2013, 2013.

Lin, G., Penner, J. E., Flanner, M. G., Sillman, S., Xu, L., and Zhou, C.: Radiative forcing of organic aerosol in the atmosphere and on snow: Effects of SOA and brown carbon, J. Geophys. Res.-Atmos., 119, 7453-7476, https://doi.org/10.1002/2013JD021186, 2014.

Mahowald, N. M., Kloster, S., Engelstaedter, S., Moore, J. K., Mukhopadhyay, S., McConnell, J. R., Albani, S., Doney, S. C., Bhattacharya, A., Curran, M. A. J., Flanner, M. G., Hoffman, F. M., Lawrence, D. M., Lindsay, K., Mayewski, P. A., Neff, J., Rothenberg, D., Thomas, E., Thornton, P. E., and Zender, C. S.: Observed 20th century desert dust variability: impact on climate and biogeochemistry, Atmos. Chem. Phys., 10, 10875-10893, https://doi.org/10.5194/acp-10-10875-2010, 2010.

McConnell, J. R., Aristarain, A. J., Banta, J. R., Edwards, P. R., and Simões, J. C.: 20th-Century doubling in dust archived in an Antarctic Peninsula ice core parallels climate change and desertification in South America, P. Natl. Acad. Sci. USA, 104, 57435748, https://doi.org/10.1073/pnas.0607657104, 2007.
Moosmüller, H., Chakrabarty, R. K., and Arnott, W. P.: Aerosol light absorption and its measurement: A review, J. Quant. Spectrosc. Ra., 110, 844-878, https://doi.org/10.1016/j.jqsrt.2009.02.035, 2009.

Moosmüller, H., Chakrabarty, R. K., Ehlers, K. M., and Arnott, W. P.: Absorption Ångström coefficient, brown carbon, and aerosols: basic concepts, bulk matter, and spherical particles, Atmos. Chem. Phys., 11, 1217-1225, https://doi.org/10.5194/acp11-1217-2011, 2011.

Moosmüller, H., Engelbrecht, J. P., Skiba, M., Frey, G., Chakrabarty, R. K., and Arnott, W. P.: Single scattering albedo of fine mineral dust aerosols controlled by iron concentration, J. Geophys. Res.-Atmos., 117, D11210, https://doi.org/10.1029/2011JD016909, 2012.

Nolin, A. W. and Dozier, J.: A Hyperspectral Method for Remotely Sensing the Grain Size of Snow, Remote Sens. Environ., 74, 207216, https://doi.org/10.1016/S0034-4257(00)00111-5, 2000.

Oris, F., Asselin, H., Ali, A. A., Finsinger, W., and Bergeron, Y.: Effect of increased fire activity on global warming in the boreal forest, Environ. Rev., 22, 206-219, https://doi.org/10.1139/er-20130062, 2014.

Painter, T. H., Barrett, A. P., Landry, C. C., Neff, J. C., Cassidy, M. P., Lawrence, C. R., McBride, K. E., and Farmer, G. L.: Impact of disturbed desert soils on duration of mountain snow cover, Geophys. Res. Lett., 34, L12502, https://doi.org/10.1029/2007GL030284, 2007.

Painter, T. H., Deems, J. S., Belnap, J., Hamlet, A. F., Landry, C. C., and Udall, B.: Response of Colorado River runoff to dust radiative forcing in snow, P. Natl. Acad. Sci. USA, 107, 1712517130, https://doi.org/10.1073/pnas.0913139107, 2010.

Painter, T. H., Skiles, S. M., Deems, J. S., Bryant, A. C., and Landry, C. C.: Dust radiative forcing in snow of the Upper Colorado River Basin: 1. A 6 year record of energy balance, radiation, and dust concentrations, Water Resour. Res., 48, W07521, https://doi.org/10.1029/2012WR011985, 2012.

Painter, T. H., Skiles, S. M., Deems, J. S., Brandt, W. T. and Dozier, J.: Variation in Rising Limb of Colorado River Snowmelt Runoff Hydrograph Controlled by Dust Radiative Forcing in Snow, Geophys. Res. Lett., 45, 797-808, https://doi.org/10.1002/2017GL075826, 2018.

Patterson, E. M. and McMahon, C. K.: Absorption characteristics of forest fire particulate matter, Atmos. Environ., 18, 2541-2551, https://doi.org/10.1016/0004-6981(84)90027-1, 1984.

Peltoniemi, J. I., Gritsevich, M., Hakala, T., DagssonWaldhauserová, P., Arnalds, Ó., Anttila, K., Hannula, H.-R., Kivekäs, N., Lihavainen, H., Meinander, O., Svensson, J., Virkkula, A., and de Leeuw, G.: Soot on Snow experiment: bidirectional reflectance factor measurements of contaminated snow, The Cryosphere, 9, 2323-2337, https://doi.org/10.5194/tc9-2323-2015, 2015.

Piedra, P. G., Llanza, L. R., and Moosmüller, H.: Optical losses of photovoltaic modules due to mineral dust deposition: Experimental measurements and theoretical modeling, Sol. Energy, 164, 160-173, https://doi.org/10.1016/j.solener.2018.02.030, 2018.

Qian, Y., Yasunari, T. J., Doherty, S. J., Flanner, M. G., Lau, W. K. M., Ming, J., Wang, H., Wang, M., Warren, S. G., and Zhang, R.: Light-absorbing particles in snow and ice: Measurement and 
modeling of climatic and hydrological impact, Adv. Atmos. Sci., 32, 64-91, https://doi.org/10.1007/s00376-014-0010-0, 2015.

Querry, M. R.: Optical Constants, Report No. AD-A158 623, Aberdeen Proving Ground, MD,available at: https://apps.dtic.mil/ dtic/tr/fulltext/u2/a158623.pdf (last access: 17 December 2018), 1985.

Reid, J. S., Koppmann, R., Eck, T. F., and Eleuterio, D. P.: A review of biomass burning emissions part II: intensive physical properties of biomass burning particles, Atmos. Chem. Phys., 5, 799825, https://doi.org/10.5194/acp-5-799-2005, 2005.

Samburova, V., Connolly, J., Gyawali, M., Yatavelli, R. L. N., Watts, A. C., Chakrabarty, R. K., Zielinska, B., Moosmüller, H., and Khlystov, A.: Polycyclic aromatic hydrocarbons in biomass-burning emissions and their contribution to light absorption and aerosol toxicity, Sci. Total Environ., 568, 391-401, https://doi.org/10.1016/j.scitotenv.2016.06.026, 2016.

Schaepman-Strub, G., Schaepman, M. E., Painter, T. H., Dangel, S., and Martonchik, J. V.: Reflectance quantities in optical remote sensing - definitions and case studies, Remote Sens. Environ., 103, 27-42, https://doi.org/10.1016/j.rse.2006.03.002, 2006.

Seinfeld, J. H. and Pandis, S. N.: Atmospheric Chemistry and Physics: From Air Pollution to Climate Change, Third., John Wiley \& Sons, Inc., 2016.

Sengupta, D., Samburova, V., Bhattarai, C., Kirillova, E., Mazzoleni, L., Iaukea-Lum, M., Watts, A., Moosmüller, H., and Khlystov, A.: Light absorption by polar and non-polar aerosol compounds from laboratory biomass combustion, Atmos. Chem. Phys., 18, 10849-10867, https://doi.org/10.5194/acp-18-108492018, 2018.

Singh, S. K., Kulkarni, A. V., and Chaudhary, B. S.: Hyperspectral analysis of snow reflectance to understand the effects of contamination and grain size, Ann. Glaciol., 51, 83-88, https://doi.org/10.3189/172756410791386535, 2010.

Skiles, S. M., Painter, T. H., Deems, J. S., Bryant, A. C., and Landry, C. C.: Dust radiative forcing in snow of the Upper Colorado River Basin: 2. Interannual variability in radiative forcing and snowmelt rates, Water Resour. Res., 48, W07522, https://doi.org/10.1029/2012WR011986, 2012.

Skiles, S. M., Painter, T., and Okin, G. S.: A method to retrieve the spectral complex refractive index and single scattering optical properties of dust deposited in mountain snow, J. Glaciol., 63, 133-147, https://doi.org/10.1017/jog.2016.126, 2017.
Skiles, S. M., Flanner, M., Cook, J. M., Dumont, M., and Painter, T. H.: Radiative forcing by light-absorbing particles in snow, Nat. Clim. Change, 8, 964-971, https://doi.org/10.1038/s41558-0180296-5, 2018.

Sumlin, B. J., Pandey, A., Walker, M. J., Pattison, R. S., Williams, B. J., and Chakrabarty, R. K.: Atmospheric Photooxidation Diminishes Light Absorption by Primary Brown Carbon Aerosol from Biomass Burning, Environ. Sci. Technol. Lett., 4, 540-545, https://doi.org/10.1021/acs.estlett.7b00393, 2017.

Sumlin, B. J., Heinson, Y. W., Shetty, N., Pandey, A., Pattison, R. S., Baker, S., Hao, W. M., and Chakrabarty, R. K.: UV-Vis-IR spectral complex refractive indices and optical properties of brown carbon aerosol from biomass burning, J. Quant. Spectrosc. Ra., 206, 392-398, https://doi.org/10.1016/j.jqsrt.2017.12.009, 2018.

Thomas, W. H. and Duval, B.: Sierra Nevada, California, U.S.A., Snow algae: snow albedo changes, algal-bacterial interrelationships, and ultraviolet radiation effects, Arct. Alp. Res., 27, 389, https://doi.org/10.2307/1552032, 1995.

Waddington, E. D., Cunningham, J., and Harder, S. L.: The Effects of Snow Ventilation on Chemical Concentrations, in: Chemical Exchange Between the Atmosphere and Polar Snow, Springer Berlin Heidelberg, Berlin, Heidelberg, 403-451, 1996.

Warren, S. G.: Optical properties of snow, Rev. Geophys., 20, 6789, https://doi.org/10.1029/RG020i001p00067, 1982.

Warren, S. G. and Wiscombe, W. J.: A Model for the spectral albedo of snow. II: snow containing atmospheric aerosols, J. Atmos. Sci., 37, 2734-2745, https://doi.org/10.1175/15200469(1980)037<2734:AMFTSA>2.0.CO;2, 1980.

Wu, G., Xu, T., Zhang, X., Zhang, C., and Yan, N.: The visible spectroscopy of iron oxide minerals in dust particles from ice cores on the Tibetan Plateau, Tellus B, 68, 29191, https://doi.org/10.3402/tellusb.v68.29191, 2016.

Zhang, X. L., Wu, G. J., Zhang, C. L., Xu, T. L., and Zhou, Q. Q.: What is the real role of iron oxides in the optical properties of dust aerosols?, Atmos. Chem. Phys., 15, 12159-12177, https://doi.org/10.5194/acp-15-12159-2015, 2015.

Zhou, Y., Wang, X., Wu, X., Cong, Z., Wu, G., and Ji, M.: Quantifying light absorption of iron oxides and carbonaceous aerosol in seasonal snow across Northern China, Atmosphere, 8, 63, https://doi.org/10.3390/atmos8040063, 2017. 